\title{
Historical Documentary Gender Identities in Goumenissa of Greece Multimodal Research Material
}

\author{
Maria Kiouzepi ${ }^{1}$, Despina Kavallari ${ }^{1}$, Athanasios Staurou ${ }^{1}$ \& Ifigenia Vamvakidou ${ }^{1}$ \\ ${ }^{1}$ University of Western Macedonia \\ Correspondence: Maria Kiouzepi, University Of Western Macedonia, Greece
}

Received: March 10, 2019 Accepted: April 23, 2019 Online Published: May 5, 2019

doi:10.5539/res.v11n2p59 URL: https://doi.org/10.5539/res.v11n2p59

\begin{abstract}
The subject of this research proposal concerns the gender representations of women in the border town of Goumenissa, a regional unit of Kilkis in Greece, as these representations are constructed on their speech. Goumenissa has been a meeting place of different origin communities, such as local, Pontiac and east Rumelia populations, after the Turco-Greek exchange of populations in Greek national history during the 1920s. The aim of this on-site research is to investigate and map out the status of the refugee and local women of Goumenissa, in years of turbulence and intensity. The research questions concern three basic thematic units: House working - Working outside, the house - Education/family constraints. What is their insight into family relationships, tradition, education and participation in production? How did they define themselves and were defined by others throughout the historical and social conditions? What kind of imprints did these conditions leave on them? How do they continue today? This on-site historical research was based on individual or group interviews and on professional filmmaking in the area of Goumenissa by the two educators Kiouzepi \& Kavallari. The outcome-deliverable has been a historical documentary based on the primary original material coming from the women's interviews that could be used as a multimodal material within an interdisciplinary approach in teaching social subjects. The theoretical axes of the research are the history of gaze, the cultural studies, the socio-semiotics and the expansion of sources in the local and oral historiography.
\end{abstract}

Keywords: Goumenissa, local communities, gender studies, historical fieldwork, documentary

\section{Introduction}

\section{About the geographical documentation}

There are a lot of versions of the origin of the name Goumenissa. According to the local tradition, robbers hung the Abbot

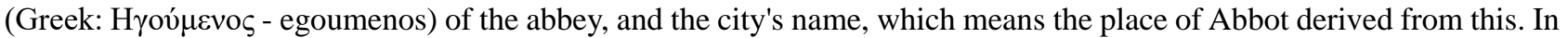
Bulgarian, it was called as Гуменидже -Gumenidzhe. The town is located in the part of the ancient Paeonia, the exact boundaries of which, like the early history of its inhabitants, are very obscure. According to Herodotus (v. 16), they were Teucrian colonists from Troy. Homer (Iliad, book II, line 848) speaks of Paeonians from the Axios river fighting on the side of the Trojans, but the Iliad does not mention whether the Paeonians were kin to the Trojans. Homer gives the Paionian leader as a certain Pyraechmes; later on in the Iliad a second leader is mentioned, Asteropaeus son of Pelagon (Altikis, 1995).

In this historical research we choose to produce a documentary using the social historiography methods.

The specific stages are these of Pre-research, Material collection, Dekampage, Direction-Editing-Mix. The local research was carried out, with participatory observation, open discussions, semi-structured and guided interviews.

At the pre-research stage there was also bibliographic research, detection of mediators, acquaintance with the field-area, the preconditions and mainly the process of building climate of trust between them and the interviewees. Then, decision on the final axes of research were made. Other decisions as the content of the interviews, the identification of possible external and internal sites for interviews and exploration for the technical equipment that will be needed, had to be taken as well. During the main survey, a recording calendar, and the meetings of the research team was held, as a feedback evaluation in relation to the course of the survey.To achieve the final outcome, pictorial analysis and interpretation, material evaluation from a technical point of view, decisions on the selection of the final material included, its composition, the detection of appropriate music and sound investment were made. For the selection of the material, basic questions had to be answered, such as: -What is the geographical and historical context of the region? -Which are the communities from which these women come from and which ones are the dominant ones? -Is it a narrative of real events 
of the past? -How is the transition from individual to collective memory through narrative?

In general, the historic documentary narrates oral testimonies, women's attitudes, stereotypes, their perceptions, and the published official national historiography. Its final duration is about 45 minutes.

The novelty of this proposal concerns the virtualization of the produced multimodal digital text, which was designed, recorded, edited and attributed by the same research team.

\section{The Production Process}

The production of a documentary from the phase of the pre-research and the collection of material to the design of the narrative-scenario (Dekampage), the Direction and the Editing, with all what this implies, is a particularly demanding process. The shootings lasted 2 months and before that, one month research was conducted to decide the exact subject of the survey, to find the appropriate mediators and to be familiar with space and persons. Bibliographic research was mainly achieved through the Municipality library of Goumenissa and other written material was collected from individuals and photo presentations of the "Ark" of Goumenissa, who gave important info for the history of the place and the social life of women. Basic woman mediator was found after searching for persons capable of transferring as close to reality as possible to the Goumenissa communities.

Many visits in the town were paid to acquire direct contact with the city environment. At first contacts were made with representatives of the Municipality from whom we got the first official information on the communities and then with the boards of the three main cultural clubs of the city that collaborated with us from the very beginning: "Diogenes of Sinope" (Pontiacs), "Paeones" (Locals) and "Agios Tryfonas" (East Rumelia).The main interviewees were selected to represent each community. Most of the interviews were taken mainly at home cause the interviewees felt more comfortably. External sessions also concerned festive events, neighborhoods, buildings of interest. Meanwhile throughout the process from the pre-research phase and on, researches the contact with the supervisor, prof. Vamvakidou, has been on going. There was support on theoretical issues, methodology of historical field research, as well as discussions about practical issues that arose in shooting.

\section{Theoretical and Methodological Models}

The theoretical axes of this research are the historic and cultural studies, the expansion of sources in local and oral historiography and the gender analysis. In visual material we also focus on the gaze, as a technical term that was originally used in film theory in the 1970s, but is now widely used by media theorists to refer both to the ways in which viewers see images of people in any visual medium and to the sight of those depicted in visual texts (see in Chandler, 1999, 2002, Ellis, 1982). The aim of this local historical research is the production of the cinematographic material in order to highlight the history of gender representations in the encounter of the groups, populations and communities that are located in the area from 1920s on.

For producing and choosing the images and the women's speeches we follow Ferro (2001) criteria. The semiotic method of analysis is also "suitably suited to exploring coproductive meanings" (Metz, 1981, Barthes, 1979, 1985). In this case, that of the documentary, we have a combination of moving image and oral speech/interviews. Semiotic analysis is a suitable method for the classification and production of the film material on the axes of the exemplary and structural image.

Some main types of gaze that can be recognized in cinematographic texts refer to who looks, so the following are more common (Chandler, 1999): • the viewer's look: the look of the viewer looking at the image of a person (or object) within the film narrative, $\bullet$ the intro-narrative look: the look of an imagined person pointing to another through subjective reception with a view, •the direct (or extra-narrative) look towards the viewer looks out of the frame (Kress $\&$ van Leeuwen, 1996: 130-135, Tuchman, 1978: 116-120). Empirical studies have shown that the closest shots lead to tension and attention and engagement. Image magnification on television may also give the impression that the person depicted is more important (Donsbach, Brosius \& Mettenklott 1993, in Messaris, 1997: 29).

\subsection{Narrative Function and Historicity}

Ricoeur (1990: 56-57) compares the terms "narrative function and historicality" by saying that at the level of the narrative, the narrative is distinguished in two radically different types: the true or empirical narration, namely the story, and the fictional narrative. These two types of narrative seem to have no common reference points: "The fictional narrative is based on facts and characters of imagination, while History has true references, mentioned in the past and documented by sources". This is the positive view of the work of history, that is, it undertakes the "revelation of the events buried in the documents". According to the most recent epistemology, represented by Collinwood, Raymon Aron, Henri Marrou and Paul Veyne, there is a gap between what actually happened and what we historically know happened. History is a reconstruction of the past and replaces the real event (Ricoeur, 1990: 59-60). The criticism of literature and especially the semiotics of narration went a step further, contributing to the creation of a general concept of the fictional representation 
of reality, including the writing of History and fiction. Ricoeur explains (1990: 65) that as much a fiction as if it is a historical text, it does not cease to be a representation of reality. History, in other words, is also a literary artifact, because it follows the rules and the symbolic system of literature, but also the representation of reality, since the events narrated are real.

\subsection{About the Nomenclature of the Term "Documentary"}

In February 1926, John Grierson, in a reference to Robert Flaherty's film, Moana, used the term "documentary" for the first time in New York's newspaper: New York. The term does not appear for the first time in the cinema vocabulary. In French, the term "documentaire" is already used to describe travel films. Grierson later gives another meaning to the term, saying it is "the creative vision of reality". This first definition given by the "godfather" of the documentary is of great importance. Grierson believes that in this area of cinema we have as a raw material the reality, which is not imprinted as a mere copying on the film, but the creator processes it before giving the film product, his film. Even today, though almost 85 years have passed, this intellectual process that is necessary for the creation of a documentary film has not been understood. The story of the documentary, however, coincides with the history of cinema. For example, "La sortie de l'usines Lumiere", 1895, could be said to be a documentary, filmed by Luis Lumiere, referring to his business. In fact, because the camera is first placed above the eye of the receiving person, we have the first concept of art. But we cannot talk about an artwork. The same can be said about newsreels. In both cases, we are dealing with a reference rather than an artistic creation.

\subsection{Material Selection Method/ Historical Documentary Method}

The Panofsky iconographic model was chosen for the selection of the supertitles and titles and the VCD's introductory elements at the beginning and end that are not part of the documentary, as defined by Derida (see in Skarpelos, 2000). For this purpose, the material was classified by following three steps: 1 . Pre-illustrative reading, 2 . Illustrative analysis and 3. Illustrative interpretation.

Some examples of questions which we discussed before and during the collection of the material with on-site participatory observation and open, but semi-structured interviews and with organized downloads were as follows: - Cinematic/novel worlds are parasites of the real? Are they microcosms that delimit most of our potentials within the real world, are they ontologically richer/poorer? •Do we find out our view of the real? Our perceptions of the truth? How does the myth work? What is the true privilege of the novels? (Eco, 1996: 118-121). -What is the presence of viewers in the plot? Are they a basic component of the story telling process, but also of the narrative itself? $\bullet$ What is the speed or the indolence in narrative? Every narrative necessarily has a fast rhythm with incidents and characters and every text is a lazy machine that asks for viewers. How elliptical is the narrative? Can viewers make choices at all times? Which shape of the reader's encyclopedia requires the text? What is the intertextuality in the project? $\bullet$ Is this a narrative of real facts of the past? Is it a linking function of memory, for the passage from individual to collective memory through narrative as the organizational principle of speech? (Greimas \& Courtes, 2008). - Do we find in the work the creator/director/orderer model, in terms of style, narrative strategy, all the instructions it gives? Do we locate the model-readers (Eco, 1996: 20-30) as ideal readers whom the work creates, willing to accept it beyond the commonplace and sensibility? $\bullet$ How is space given? What is the geographical/topographical dimension? The description in the work touches the human scale as it goes from topography to history, from collective to personal history without ever colliding and / or being identified.

\section{The Thematics}

\section{Thematics and Ways of women are provided through interview}

\subsection{House Working}

Goumenissa was a meeting place for the refugee and local element as in many places in the wider region of Macedonia (19th-20th) (Vacalopoulos, 2003, 2007, 2010, Giannakis, 1992). It seems that many elements differentiate these historical populations, but many also unite them: the common component for all the populations is their struggle for survival. The local patriarchal family of Goumenissa mainly deals with agricultural and live stock activities, which forces all its members into hard manual labor. Women also assumed the responsibility of maintaining the home and bringing up children. At the same time the newly-populated and numerous families of the refugees had to face their new situation even more urgently given their fortune destruction. Thus, they are more dynamic at work, essentially a one-way street to rebuild their home and their properties from the start. Here again, the women's population has made the most of it both inside and outside the home.

\subsection{Working Outside the House}

This unit relates to the working conditions of women outside the house, in particular at the "Chrysalis" Silk factory, a factory located within the village of Goumenissa and occupied, from 1930-1988, by an overwhelming majority of local or Eastern Rumelia women population (450 workers). We follow through the narratives the production line, starting from the 
raw material "cocoon" to the final product the silk thread, which depicts the working conditions of women as well as the relations of power developed through their professional roles e.g. "Masters ", the " Teasers " who were trained to be Masters in the future, the "akrodestres" and the "Forewomen", responsible for the coordination of production and shifts. The research also highlights the difficult conditions in which women worked as the humidity, the odor of the cocoon, the hot and cold water switching, with bare hands preparing the raw material for the masters, complement the pressing factory working shift. However, although the wage as recorded in the survey was low for the trainees and higher for the Masters, it was considered to be more preferable than the uninsured other seasonal agricultural work.

\subsection{Education/Family Constraints}

This unit records data on Women's Education, Relations with family members and Woman as a continuation of the tradition and culture of the group. The documentary records women's education in the first, second and third generation of Goumenissa after the influx of refugee populations. A general assumption is the fact of the incomplete education of women of the first and second generation. The reasons given are summarized as follows: The poor economic situation and the need for survival for both indigenous and refugee populations force all family members to work in rural activities. Of course, women collectively take on the role of the mother and the caretaker of the house and all of her family members. On the basis of the above, every effort to educate women turns out to be pointless and untimely in view of the intended dual role of this of the mother and the housewife even in cases where this was required. The feeling and the conviction that school is hard and makes you suffer is dominant, therefore sensitive personalities like women will not succeed in school life. Education, skills acquisition can eventually lead to the rise and lead young women to arrogant behavior and not to work as housewives. This view is recorded in the documentary twice by both a man and a woman. The above-mentioned views led women to marriage at an early age. In the present study, fourteen, sixteen years of age are reported. Minor girls who were called upon to take up the burden of everyday life in the home, the care of the patriarchal family, and, more generally, the service of needs based on the hegemonic relations of the older family members in them, which were manifested in various ways. Some characteristic examples taken from the interviews are that of the Pontic custom "mash" where the bride had to regularly kiss the hand of her father-in-law within the framework of subordination or banning the externalization of feelings of joy or sadness even in the case of a child's death. The ban on initiative or expression of opinion also complements women's living conditions. Aggregate data shows that women comprise about 43 percent of the agricultural labour force globally and in developing countries. But this figure masks considerable variation across regions and within countries according to age and social class. Time use surveys, which are more comprehensive but typically not nationally representative, add further insight into the substantial heterogeneity among countries and within countries in women's contribution to agriculture. They show that female time-use in agriculture varies also by crop, production cycle, age and ethnic group. A few time-use surveys have data by activity and these show that in general weeding and harvesting were predominantly female activities. Overall the labour burden of rural women exceeds that of men, and includes a higher proportion of unpaid household responsibilities related to preparing food and collecting fuel and water. The contribution of women to agricultural and food production is significant but it is impossible to verify empirically the share produced by women. Women's participation in rural labor markets varies considerably across regions, but invariably women are over represented in unpaid, seasonal and part-time work, and the available evidence suggests that women are often paid less than men, for the same work. This paper re-affirms that women make essential contributions to agriculture and rural enterprises across the developing world. But there is much diversity in women's roles and over-generalization undermines policy relevance and planning. The context is important and policies must be based on sound data and gender analysis agricultural and rural activities (see in http://www.fao.org/publications/sofa/en/).

\section{Profiles of the Origin Communities of Research Subjects}

Women interviewed in the town of Goumenissa live in the current capital of the Peony District of Kilkis Prefecture in Central Macedonia, Greece, $69 \mathrm{~km}$ NW from Thessaloniki, $20 \mathrm{~km}$ north of Pella and very close to the Fyrom border. The population of the Municipality of Goumenissa in the 2001 census was 4,073 inhabitants. Women interviewees come from three different origin communities, the Pontiacs, the East Rumelias and the Locals. The Goumenissa Pontiacs originate from Ak-Dag-Maden (White Mountain Mines) located in Turkey and specifically in the province of Ankara. In 1924, after the Asia Minor catastrophe and population exchange with Greece, approximately 1,000 people and 15 families from the city of Takati (ancient Evdokia) settled in Goumenissa. At home, there were merchants, landowners, shopkeepers, craftsmen, blacksmiths, and coaches. Many immigrated for the second time to other Greek cities, Australia and Germany. Today, the Goumenissa Pontians are 300-350 people. The 120 East Rumelia families, who came to Goumenissa also with the exchange of populations in 1924-1925 came from Upper Vodenos, Stenimachus of Eastern Rumelia. In the homeland they cultivated vines and their wines were famous for their quality. The same they continued to do in Goumenissa, reviving most of their traditional customs. The locals are recorded in the area in the settlements from which the present town came from the southwest of today's Goumenissa and were occupied with agricultural and livestock activities. The 853 AD Slavs, probably Dragouvites, invaded the area and became the rulers of part of the settlements, thus evolving in 
villages with a mixed ethnological population (Altikis, 2002: $10 \&$ 2006). Greeks and Slavs forced by the looting of the Turks who had occupied the nearby Giannitsa (1387), resort to mountain or low in the valley with dense vegetation to protect themselves. With the child kidnapping, recruiting young people only from Greek families rather than from Bulgarian or Serbian, the Greek populations of the region use Slavic language this time to avoid blood taxation. Over the years, a linguistic idiom of the locals of the region has been developed, which is now spoken without any written language (Vacalopoulos, 1989, 1999, 2000, Intos, 1983, 1989, 1991, 1993, 1999, 2007, 2010).

\section{The Language Idiom Native Women Use}

In Goumenissa, as in the major region of Western Macedonia, the slav-macedonian is defined as idiom: about one in three inhabitants of Greek Macedonia spoke this idiom until 1912. In 1965, service reports estimated 130-150,000 Slav-speaking residents of only three prefectures (Florina, Kastoria and Pella). At the beginning of the 21st century this local idiom is still spoken in much of Northern Greece. Contrary to what the predominant historiography claims, the period of the Metaxian dictatorship was not the only time of persecution of the "three-sided foreign idol", but the culmination of a decades-long policy. "Banned idiom" follows this policy of repression, terror, embarrassment and "national" alarmism in its evolution from the beginning of the 20th century to the present (in Kostopoulos, 2008). Babiniotis (2008) argues that Slavomakedonika is a dialect of Greek-Bulgarian border regions, where a number of Greeks, alongside Greek, knew (the oldest) and a Bulgarian-derived dialect, as is always the case in the world with some border groups of the population of most countries. It is to be noted that due to the bilingual character of the speakers and due to its different Bulgarian dialectical origins and of course because this (exclusively oral) dialect is not ignored, such as Skopje in Bulgaria, "Slavomakedonika" do not identify with Skopje's Serbo-Bulgarian language (Babiniotis, 1992 and Babiniotis 1989: 53-69). Italian Indo-European linguist, Vittore Pisani (see in Babiniotis, 1992) supports that "Indeed, the term Macedonian language [is the language of Skopje] is the product of a policy of essentially origin." The specialist Slavic linguist, the French André Vaillant (see in Babiniotis, 1992), is the one who emphasizes that "the name "Bulgari" is in fact the national name of the Slavs of Macedonia, which shows that (the Slavs of this region) adopted the name "Bulgarians" who was given them by the Serbs". The German linguist Heinz Wendt (see in Babiniotis, 1992), speaking of Slavic languages, says: "If one is to classify the Slavic languages according to their present structure, he should consider Bulgarian and Macedonian, [meaning Skopje's language] because of their outstanding structural peculiarities, as a self-contained group and juxtapose it with all other Slavic languages".

According to prof. Dinas, Macedonia is a geographical area known since antiquity. Today, the so-called "historical" Macedonia belongs to three neighboring states, Greece (51\%), FYROM (38\%) and Bulgaria (11\%). Often the question arises: is there a "Macedonian nation" and thus "Macedonian language"? The answer is negative. Macedonia is a geographic area inhabited by a mosaic of people with different ethnic origins and languages, e.g. Greek-speaking, Vlach-speakers, Arvanitphonists, Slav-speakers, etc. All these populations are the result of the history of the area: it was inhabited in ancient times by Greek Macedonians, later with the arrival of the Romans (2nd century BC) and the Latin language there were Latin influences on existing languages and Neolatin languages (e.g. (6th-7th century AD),with the arrival of the Slavs, we have Slavic influences on the existing languages and Slavic languages (for example, the Bulgarian language) and finally, with the arrival of the Ottomans and the Turkish language we have Turkish impacts on existing languages. Of all this, obviously, neither a nation nor a language with uniform characteristics results so as to be called a "Macedonian nation" and a "Macedonian language". Thus, Fyrom as a multinational state, consisting of Slavs around $55 \%$, Albanians about 35\%, and other populations such as, Roma, they are entitled to slavic Macedonians, as Slavs who reside in a part of Macedonia, but not to Macedonians, as this is misleading (as many are Macedonians, as we have said) and leads to irredentism. Thestate could be called Slav-Macedonian, but its Albanian inhabitants are reacting to it and it is not preferred as a name. Nevertheless their language as Slavic, is a western Bulgarian dialect (see in http://users.uowm.gr/kdinas/syllogikoitomoi5/, http://users.uowm.gr/ kdinas / wp-content / uploads / 2003/01 / Language-or-dialect-Bulgaria.pdf).

\section{Results-Discussion}

The whole experience of on-site historical research proved to be particularly fruitful on many levels, both individually and as a team work. Dilemmas and queries were raised in all phases of the survey. The most important of these concerned the methodology to be followed for the approximation of individuals, the classification of the material, the writing of questionnaires, the interventions, the objectivity of the researchers and the subjectivity of the produced. Particularly important was the realization coming from action on spot, of how scientific research is connected with and is the basis for a semiotic approach to events, how historical research of the past through the semiotic point of view, comes to interpret the reality of a place and a population today and how it can affect the look of a creator. Women of Goumenissa, contributed a lot to the economic development of their society in every role assigned to them either as farmers or workers in factories or housewives though education system rather put them aside. Still, they've been evolved in a lively piece of their communities, guardians of tradition, proper management and values of life. Goumenissa region proved to be 
particularly rich in material for gender studies but also for many other than gender, kinds of research (ethnographic, folklore, architectural, etc.) and is a challenge for future researchers. The abundance and diversity of parallel to the main issue material was also the most important management issue to be addressed in this research.

Women's history and oral history grew up together. Each developed from a commitment to reveal and reverse, to challenge and to contest what were perceived to be dominant discourses framed by gender and class. In this article the relationship between these two endeavors is explored. Beginning with the 1960s the influence of feminist approaches to research and representation are given due consideration and acknowledgement. In reviewing changes over the last four decades the dilemma for women of being both subject and object in research is explored. The tension in this dilemma is discussed in relation to developments in relation to subjectivity in the interview, the process of doing oral history, the developments in public history and remembering in late life. This paper, using the documentary production concludes with an overview of new work in the field and concedes that, whatever issues remain unresolved, oral history continues to interest and attract researchers working in a wide range of disciplines with the promise of yet more theorized and gendered explorations of the past in years to come. The narratives thus produced are used to explore the ways in which cultural discourses and personal memory intersect to create individual accounts of historical experience. Summerfield argues that "personal narratives draw on the generalized subject available in discourse to construct the particular personal subject," and that it is therefore "necessary to encompass within oral history analysis and interpretation, not only the voice that speaks for itself, but also the voices that speak to it, the discursive formulations from which understandings are selected and within which accounts are made" (Giles, 2000).

It is these local slippages that offer opportunities for understanding the ways in which interiority and public discourse intersect in individual women's voices.

\section{Reference}

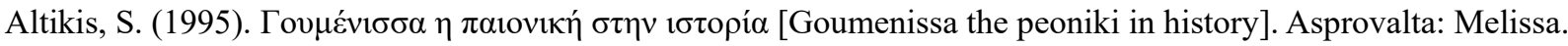

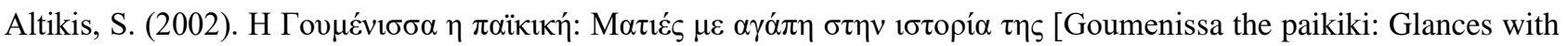
love in her history]. Asprovalta: Melissa.

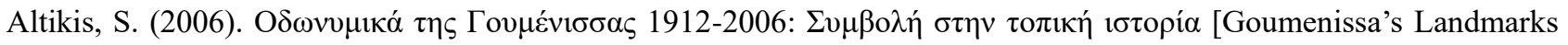
1912-2006: Contribution to local history]. Asprovalata: Melissa.

Audiovisual Archive in Greece

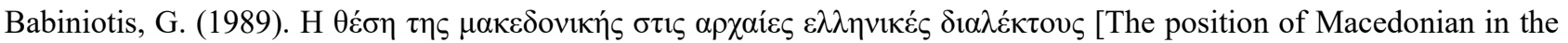

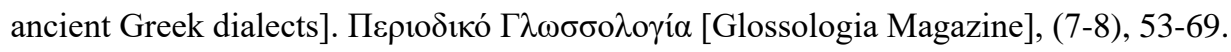

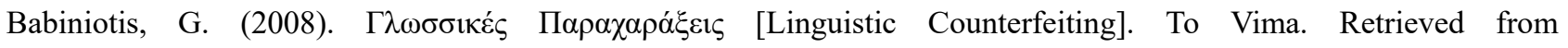
https://www.tovima.gr/

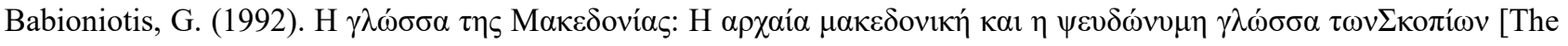
language of Macedonia: The ancient Macedonian language and the pseudonymous language of Skopje]. Athena: Olkos.

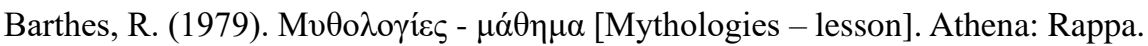

Barthes, R. (1985). L'aventure semiologique. Paris: aux Editions du Seuil.

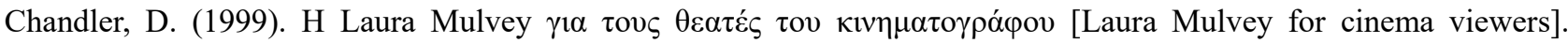

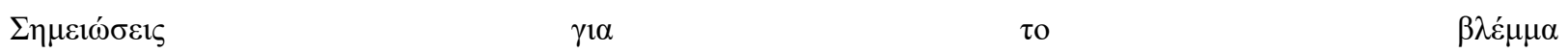

[Notesforthelook].http://visual-memory.co.uk/daniel/Documents/gaze/greek/gaze09_greek.html .

Chandler, D. (2002/2007). Semiotics: The Basics. London: Routledge. https://doi.org/10.4324/9780203014936

Dinas, K. (2003). Г

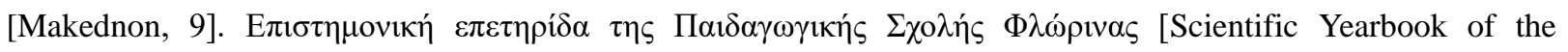
Pedagogical School of Florina], pp. 139-160.

Donsbach, W., Brosius, H-B., \&Mattenklott, A. (1993). The Guided Eye: Channel and Presentation Effects in Personal and Televised Perceptions of an Event. Paper presented to the International Communication Association, Washington, DC (May).

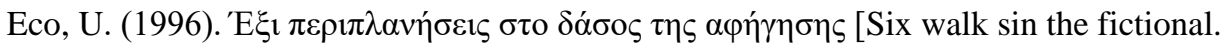


Ellis, J. (1982). Visible Fictions: Cinema, Television, Video. London: Routledge.

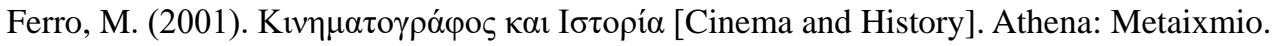

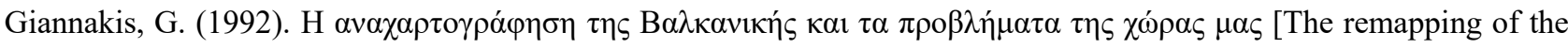
Balkans and the problems of our country]. Thessaloniki: Private Version.

Giles, J. (2010). Reconstrucing Women's Wartime Lives: Discourse and Subjectivity in Oral Histories of the Second World War”. Biography, 23(3), 2000, 552-555. https://doi.org/10.1353/bio.2000.0027

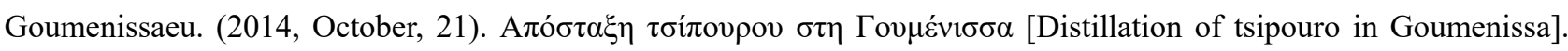

Retrieved from https://www.youtube.com/watch?v=2kWg3JUxDI4\&nohtml5=False

Greimas, A. J., \& Courtes, J. (2008). Dicionário de semiótica. São Paulo: Contexto.

http://users.uowm.gr/kdinas/syllogikoitomoi5/, http://users.uowm.gr/ kdinas / wp-content / uploads / 2003/01 /

Language-or-dialect-Bulgaria.pdf

http://www.fao.org/publications/sofa/en/).

https://muse.jhu.edu/article/5065/summary

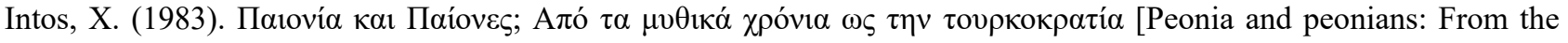
mythical years to the Ottoman domination]. Kilkis: O maxitis.

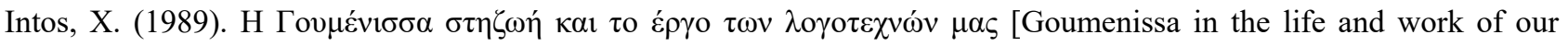
writers]. Thessaloniki: Orfanidis D.

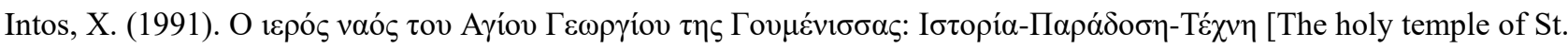
George of Goumenissa: History-Tradition-Art]. Thessaloniki: Orfanidis D.

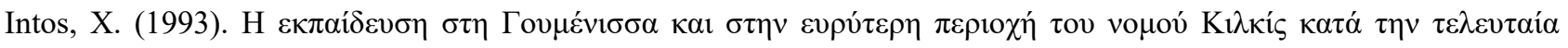

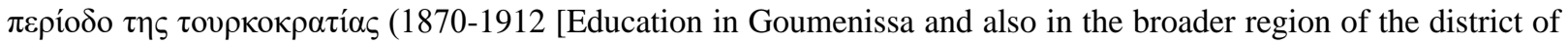
Kilkis city in the last period of Ottoman domination (1870-1912)]. Thessaloniki: Orfanidis D.

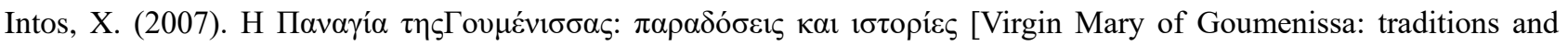
stories]. Kilkis: Maxitis.

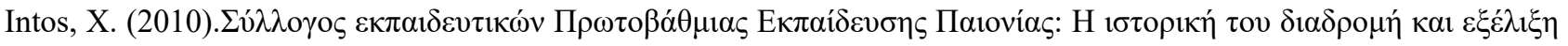
1920-2010 [Teachers Association of Primary Education of Peonias region: its historical route and progress 1920-2010]. Kilkis: Maxitis.

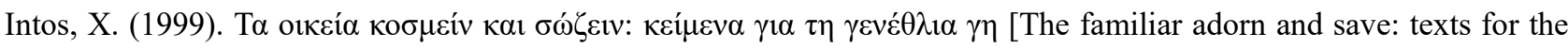
birthday land]. Kilkis: Maxitis.

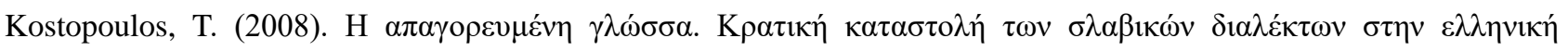

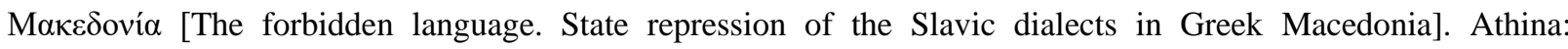
Vivliorama.

Kress, G, \& Van Leeuwen, T. (1996). Reading Images: The Grammar of Visual Design. New York: Routledge.

Melikis. G. (Reporter). (2012, September, 18). O тó Rertieved from https://www.youtube.com/watch?v=rPDyBn39zgM

Messaris, P. (1997). Visual Persuasion: The Role of Images in Advertising. London: Sage

Metz, C. (1981) Methodological propositions for the analysis of film, in Eaton (ed.) (1981), pp. 86-98.

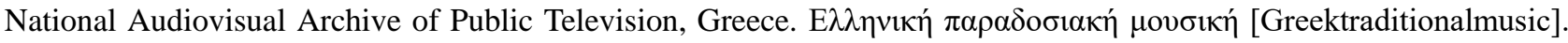
Retrieved from https://archive.ert.gr/

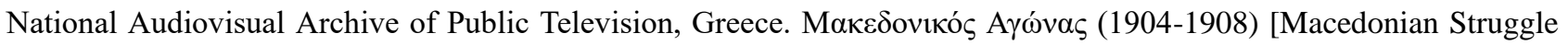
(1904-1908)]. Part 1. Retrieved from https://archive.ert.gr/

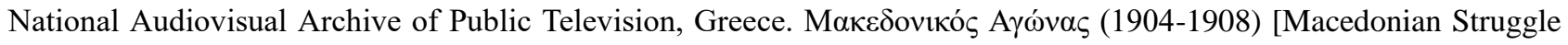
(1904-1908). Part 2. Retrieved from https://archive.ert.gr/ 


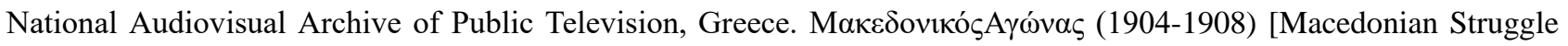
(1904-1908)].Part 3. Retrieved from https://archive.ert.gr/

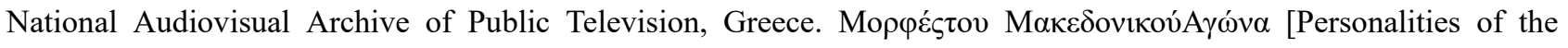
Macedonian Struggle]. Retrieved from https://archive.ert.gr/

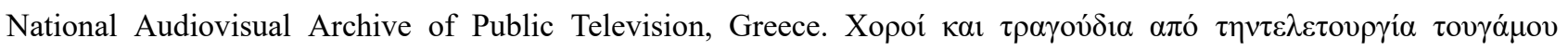
[Dances and songs from the marriage ritual]. Retrieved from https://archive.ert.gr/

Ricoeur, P. (1990). H $\alpha \varphi \eta \gamma \eta \mu \alpha \tau \iota \kappa \eta ́ ~ \lambda \varepsilon ı \tau o v \rho \gamma i ́ \alpha$ (la function narrative) Athina: Kardamitsa.

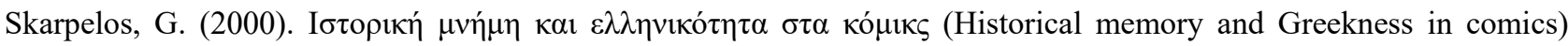
Athina: Kritiki.

Tuchman, G. (1978). Making News: A Study in the Construction of Reality. New York: Free Press.

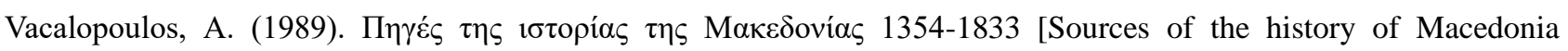
1354-1833]. Thessaloniki: Society for Macedonian Studies.

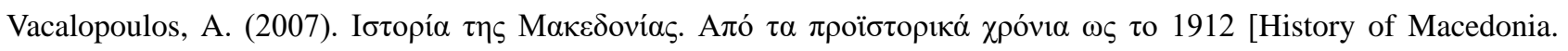
From prehistoric years to 1912]. Thessaloniki: Society for Macedonian Studies.

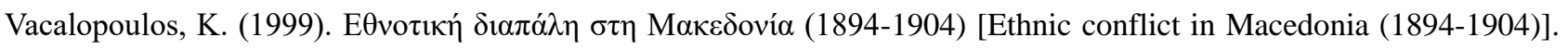
Athena: Irodotos.

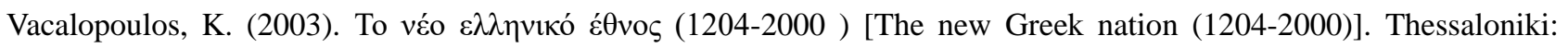
Stamoulis.

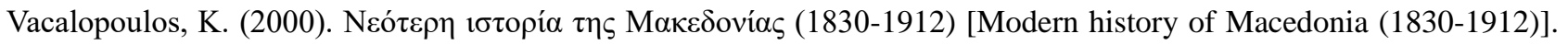
Athena: Stamoulis.

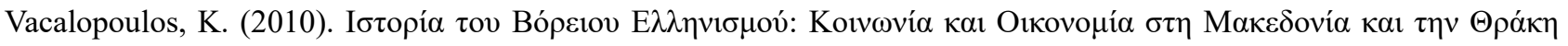

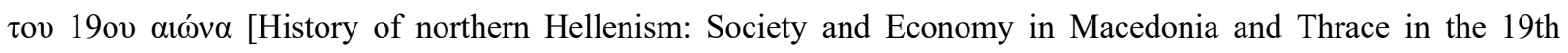
century]. Thessaloniki: Stamoulis.

\section{Copyrights}

Copyright for this article is retained by the author(s), with first publication rights granted to the journal.

This is an open-access article distributed under the terms and conditions of the Creative Commons Attribution license (http://creativecommons.org/licenses/by/4.0/). 